\title{
CORRECTIONS
}

\section{Use of $\mathrm{HbA}_{1 \mathrm{c}}$ in the diagnosis of diabetes}

This Editorial misquotes the 2011 World Health Organization recommendation on the use of $\mathrm{HbA}_{1 \mathrm{c}}$ in diagnosing diabetes (BMJ 2012;345:e7293, doi:10.1136/bmj.e7293). The expert group convened by WHO approved $\mathrm{HbA}_{1 \mathrm{c}}$ as a diagnostic test for diabetes, but did not recommend that it should replace glucose measurement. Accordingly, the second sentence of the first paragraph should read "Improved standardisation in the measurement of glycated haemoglobin $\left(\mathrm{HbA}_{1 \mathrm{c}}\right)$ and wider availability of the assay led to a recommendation in 2011 by the World Health Organization that $\mathrm{HbA}_{1 \mathrm{c}}$ could [not "should"] be used instead."

Cite this as: BMJ 2012;345:e7566

๑ BMJ Publishing Group Ltd 2012 